Article

\title{
Piecemeal Integration: Explaining and Understanding 60 Years of European Union Forest Policy-Making
}

\author{
Helga Pülzl ${ }^{1, *}$, Doris Wydra ${ }^{2}$ and Karl Hogl ${ }^{3}$ \\ 1 Institute of Forest, Environmental and Natural Resource Policy, University of Natural Resources and Life \\ Sciences, Vienna (BOKU) and European Forest Institute (EFI)—Forest Policy Research Network, \\ Feistmantelstrasse 4, 1180 Vienna, Austria \\ 2 Salzburg Centre of European Union Studies (SCEUS), University of Salzburg, Mönchsberg 2, 5020 Salzburg, \\ Austria; doris.wydra@sbg.ac.at \\ 3 Institute of Forest, Environmental and Natural Resource Policy, University of Natural Resources and Life \\ Sciences, Vienna (BOKU), Feistmantelstrasse 4, 1180 Vienna, Austria; karl.hogl@boku.ac.at \\ * Correspondence: helga.puelzl@boku.ac.at; Tel.: +43-1-47654-73221
}

Received: 1 October 2018; Accepted: 14 November 2018; Published: 19 November 2018

\begin{abstract}
This article looks at forest policy as empirical case study of European integration. By applying different theoretical lenses of European integration approaches (neo-functionalism, liberal intergovernmentalism, three institutionalist approaches and constructivism), it seeks to explain and understand the integration of forest policy in the European Union during the policy's emergence (1958 to 1960s), expansion (1970 to late 1990s) and stabilization period (late 1990s to now). The findings clearly show that, to a certain extent, all European integration theories have their merits for the analysis. However, none of the employed integration theories alone can explain all the relevant aspects of the broader developments in EU forest policy. No individual theory can help explain why forest policy developed only incrementally and why it has been weakly institutionalized. This article, therefore, argues to combine them so as to establish a clearer picture of the driving factors and constraints. As each of the grand theories has its weak spots, it is further argued that scholars of European studies should work across a broader theoretical spectrum as only this would allow light to be shed on blind spots in empirical investigation over longer time periods.
\end{abstract}

Keywords: institutionalization; European integration theories; forest policy; European Union; policy-making

\section{Introduction}

1960: "A common forestry policy must find its appropriate place in the agricultural policy proper" [1]

1979:" . . requests it to proceed with the preparation of a genuine Community forestry policy" [2]

1985: "While the Commission is not proposing to establish a Community forest policy, many of the actions suggested would be more effective if taken at the level of the Community rather than at the level of individual Member States" [3]

The importance of forests, their relevance for ecosystems, their role in preventing climate change and biodiversity loss, while also providing a number of valuable products are widely acknowledged within the European Union (EU). Reasons for further integrating forest policy at the European level are manifold, primarily resulting from common interests to avoid negative externalities, e.g., soil pollution 
or extensive forest dieback due to transboundary air pollution. Further motivation in this regard comes from the goal of providing public goods of a cross-border nature, such as an EU-wide trade regime free of tariffs and non-tariff barriers, a common regime for fostering the contributions of forest management for the welfare in rural areas, the protection of forest biodiversity or the conservation of beautiful landscapes on a European scale. However, the founding treaties of the Union have made no provisions for forests or forestry, and instead, the rules of the common market were applied to agricultural products as forestry products and wood-apart from cork (included in the detailed list in Annex II of the Treaty) - which were not included therein. Nevertheless, matters concerning forests are addressed in a large number of legal and policy instruments, but a comprehensive EU-wide forestry policy was not enacted $[4,5]$. Although plans have existed since the 1960s to define a common forestry policy and later to include a chapter on forests into the Constitutional Treaty, there remains no mention of forests or forestry in the Treaty of Lisbon [6]. This is not the case for other policy areas, most prominently environmental or climate policies, which found their way into EU primary law as early as the treaty revisions introduced in Maastricht.

This current state of affairs exists despite continuous claims and attempts over a period of 60 years to move toward a more institutionalized forest policy. The question then arises as to why only very limited integration is discernible in the forest policy area even though demands for European level solutions are high. In contrast, other related policy areas have enjoyed a notable increase in their level of European integration. How can it be explained that the European Commission (EC), which is in charge of proposing legislation, as early as in the 1960s, when the Community had only six Member States, showed its keenness on formulating a legal instrument exclusively for forests, but only non-legally binding forest instruments have been developed ever since? How to get a grip on the fact that the European Parliament (EP) for the first time used its indirect right of initiative, introduced by the Treaty of Maastricht, to ask the EC to become more active with regards to forest policy, including the economic utilization of forests, but to be again of no avail? How can one understand that varying Council members have repeatedly asked to put forest policy on a much broader legal footing and put a heavy emphasis on its European dimension, but forest policy is not a strongly developed policy area? Finally, how has the process of meaning-making within the Union played out in relation to forest policy making? With regard to all of the foregoing, taking a more comprehensive view of established theories of European integration could well explain why forest policy is still relatively weakly institutionalized. To better understand the development of this particular policy field that has seemingly triggered the interest of the European institutions as well as its Member States, we suggest applying different integration theories such as neo-functionalism, liberal intergovernmentalism, institutionalism and constructivism in order to see which explanations they can provide us with. We borrow their analytical devices to analyze how forest policy in the EU has developed and why strengthening its institutionalization from a de facto policy to a de jure policy has not taken place.

For the empirical analysis, we have divided the development of forest policy in the EU into three key policy phases (emergence-1958 to the 1960s, expansion-1970 to the late 1990s, establishment-late 1990s to now). The initial phase comprises the first decade after the founding of the European Community. The second period, labeled as the expansion phase, saw a large number of forest-related policies and activities being developed, while the establishment phase starts with the solidification of the forest policy field following the issuance of the first community forestry strategy.

This article proceeds with a short discussion of the various approaches to explain European integration followed by a set of hypotheses to help explain and understand the status of forest policy institutionalization in the EU. Thereafter a discussion of EU forest policy's emergence, expansion and establishment from the perspective of these integration theories is provided. The final section discusses the results and suggests analyzing empirical phenomena such as forest policy integration from different theoretical angles simultaneously as a more nuanced understanding can be gained. As none of the theories can explain the different developments entirely (as the EU developed), it is argued that 
scholars should continue to look at European integration processes from different theoretical angles in parallel and over longer time periods than is most often currently practiced.

\section{Integration Theories}

The main function of integration theories is to explain the development of the EU from a Community of six Member States. They are mainly concerned with establishing a single market from a complex Union of twenty-eight that has introduced a commonality in currency, foreign and security policy, judicial regulations and domestic affairs as well as trying to establish its role as a normative actor in both democratic values and ecologic responsibility. Different approaches focus on different aspects of European integration: the dynamics of the integration process as a steady evolution towards "an ever closer union" (neo-functionalism); the role of bargaining processes between Member States on the basis of domestic preferences (liberal intergovernmentalism); the role of institutions and the way they change the rules of the game (three institutionalist approaches) and the role of ideas, discourses and narratives in shaping the perceived reality of actors (constructivism).

The theory of neo-functionalism, mainly drawing on the writings of Ernst B. Haas [7], emphasizes the dynamics of the integration process as a steady move towards "an ever closer union". This unidirectional process of integration is seen as the result of spill-over processes: functional spill-over, on the one hand, implying that deriving from economic demands the regulation of one policy sector triggers integration into other sectors, starting from low politics (key economic sectors) and causing an expansive logic of integration. Political spill-over, on the other hand, suggests that political elites shift their loyalties to other levels of government when looking for political solutions. Most importantly perhaps, neo-functionalism holds that games played between actors are not necessarily zero-sum games, but through agreement may upgrade the common interest [8]. Neo-functionalists hold the assumption that self-interested groups of pluralistic, industrialized and democratic societies create patterns of behavior and special organizational forms to manage transnational decision-processes [9]. Member States set the terms for the initial agreement, but are not seen as drivers to further the integration process, as they assign competences for further integration to supranational institutions; in the case of the EU, this is principally the EC [10]. Integration is, therefore, a rather apolitical process, driven by technocratic knowledge.

Neo-functionalism also challenges the concept of nation-states as unified actors, but rather looks at political and economic elites as rational and self-interested actors with the capacity to learn and change their preferences. These elites' preferences are therefore likely to change over the course of the integration process. Institutions, created originally as technocratic managers, can develop a life of their own and become independent agents for further integration [11]. Haas later characterized this as "soft rational choice", whereby "social actors, in seeking to realize their value-derived interests, choose whatever means are made available by the prevailing democratic order" [7,12].

Neo-functionalism has been heavily criticized for its unidirectionality, the lack of consideration for political processes and national interests, but also for its isolation of European integration from international developments, which may also put pressure on the specifics of the integration process. In a reaction to this criticism authors such as Lindberg [13] and Schmitter [14] took some emphasis away from the mere technocratic and automatic process of "spill-over" by stressing the "political" role of actors and focusing on actors' perceptions of tensions regarding their objectives and strategic decisions [14]. Rosamond [9] (p. 63) showed that when anticipating a particular economic environment, actors explicitly press for a deepening of economic integration. At the same time, actors' strategies were not only directed towards "spill-over", and thus towards a progress of integration. They also resulted in strategies such as "spill-around" (an increase in scope, but not authority), "build-up" (increase of decisional capacities, but with no spill-over into new areas), "spill-back" (returning to a prior status quo) or "retrench" (increase deliberations without institutionalization) [14]. Although, some sectors hold more spill-over potential than others [9] (p. 62). In order to find an explanation for weak forms of integration in specific sectors, a closer examination has to be made of actors' loyalties on the one 
hand-to business groups, lobbyists, and the respective directorates in the Commission e.g.,- - and the structural pressures arising from other, already integrated sectors.

In contrast to neo-functionalism, liberal intergovernmentalism is not process-oriented, but rather, focuses on significant events in the Union's development, especially with regard to treaty reforms. This approach is principally connected with the name of Andrew Moravcsik, who developed this theory at the beginning of the 1990s explicitly as a critique to neo-functionalism. Moravcsik summarizes the main shortcomings of neo-functionalism as: "neither the pressures from incomplete integration (functional spill-over), nor the self-reinforcing process of institution-building (political spill-over) predict the process of European evolution and result in an "indeterminate ideal-typical description of the single case of the EC" [15] (p. 476). In support of his view, he developed a theory based on several theories of the international political economy that provided three key elements: the assumption of rational state behavior, a liberal theory of national preference formation and an intergovernmental analysis of interstate negotiations [15] (p. 480). On the supply side, he conceptualized the formation of state preferences into domestic processes in which autonomous interests interact in civil society. State interests are thus neither fixed nor uniform: they vary not only among states, but also within states over time and issues, especially as various groups articulate preferences and governments aggregate them [15] (p.483); [16]; [17] (p.69). Governments, in this perspective, originally pursue integration as a means to secure commercial advantages for domestic producers and according to the macro-economic preferences of ruling government coalitions, but also taking into account geopolitical interests [16] (p. 38). Co-operation is therefore induced by the necessity to cope with negative externalities resulting from increasing the transborder flows of goods, services, but also factors such as pollutants [15] (p. 485). Accordingly, the pressure for co-ordination, coupled with the discretion of governments to act, varies between different issue areas [15] (p. 495).

This liberal theory of state preference formation is complemented with a bargaining theory, which takes into account the necessity to collectively overcome suboptimal outcomes while simultaneously deciding how mutual gains are to be distributed [17] (p. 71). Such European level bargaining games are typically characterized by their voluntariness, relatively long time-frames in an information-rich environment and that incur of low transaction costs. Players in this bargaining game unsurprisingly develop their own strategies accordingly. In the European context, bargaining power depends on the intensity of preferences taking into account unilateral policy alternatives (threat of non-agreement), alternative coalitions (threats of exclusion) and potentials for compromise and issue-linkage [15] (p. 499). Usually no third parties—such as ideational policy-entrepreneurs or supranational institutions-are required to seal efficient interstate agreements. Nevertheless, institutions still play a role as they provide specific advantages to national governments: first, they increase the efficiency of interstate bargaining as they reduce transaction costs [15] (p. 507); [18]. Second, they strengthen the autonomy of national political leaders vis-à-vis particularistic social groups back home [15] (p. 507). European institutions are considered to be the result of conscious calculations by Member States and the institutional structure of the EU is hence deemed as acceptable to national governments as it strengthens their control over their own domestic affairs [15]. Competence delegation and the pooling of sovereignty thus reflect the issue-specific concerns of national governments about the future ability to comply with any substantive deals reached. The creation of strong institutions, such as the EC and the European Court of Justice (ECJ), aims to resolve problems of control and incomplete contracting "through credible pre-commitment" [17] (p. 72). According to intergovernmentalist logic, "the essence of the EC, as a body for reaching major decisions, remains in its transaction-cost reducing function" [15] (p. 508). Accordingly, these institutions are not considered to have "a life of their own", but rather, to enjoy continued existence only by the will of the Member States.

In conclusion, from a liberal-intergovernmentalist perspective, the direction of integration is clearly dependent on the will of the Member States. Therefore, to get a clearer understanding of why specific policies are less integrated than others, domestic pressures in different Member States have to 
be analyzed, as well as how these pressures play out in bargaining processes at the European level, when major decisions-namely in the context of treaty reforms-have to be taken.

Both approaches discussed above place importance on European institutions, but give differing answers to the question of what roles these institutions play in the European integration process. Different forms of institutions exist within the EU, formal as well as informal, and Brigid Laffan [19] for instance describes the EU as an institutional field, characterized by three pillars: the regulative, the normative and the cognitive. The regulative pillar focuses on the constitutive role of law for the European Union, referring to treaties and legislation of the EU that emphasize the centrality of law and establish goals, instruments, policies and decision-making processes. The normative pillar focuses on values and norms as "guides to social and political behaviour" [19] (p. 714), including process norms (consensus between Member States, equal spread of gains and losses, maintenance of a balance between large and small states). Finally, the cognitive pillar refers to frameworks to which meaning is given, including symbols (such as common currency) and collective identities [19].

Different institutionalist approaches have tried to capture (a) the nature of the densely institutionalized field of the EU, and (b) to explain how it shapes the behavior of actors, but also (c) the integration process itself. Rational choice institutionalism, which emerged in the late 1970s, focuses on how actors design institutions to secure mutual gains [20] (p. 126). While in this model, actors' preferences exist outside of institutions (exogenous), the theoretical role of institutions is endogenous (explained in theoretical terms) [21] (p. 431). Institutions created by the players "in the game" serve to establish an equilibrium [22], meaning that the creation of institutions can therefore be explained by the wish of relevant actors to secure mutual gains as these institutions secure credible commitments. The institutions themselves follow the logic of efficiency by becoming agents of the principals (i.e., the Member States). However, the agents have their own agendas and the institutional setting may provide possibilities to "slip", thus securing the institutions' own goals rather than the principals' preferences. In this regard, the Commission has often been said to be a case in point. The principals (Member States) aim is to subordinate the agent (Commission) to different forms of control [23-25], while the agent desires to follow its own institutional logic and interests whenever possible.

Rational choice institutionalism has been used to model the relations between the different institutions of the EU [24], focusing on the ECJ, which has been established in order to solve problems of incomplete contracting. From an institutional perspective, Member States accepted ECJ jurisprudence because of their rational long-term interest in the enforcement of EU law [26]. In addition, the EC's room for maneuver, and especially its ability to propose new legislation depends not only on legislative procedures but also on the positions of the majority of Member States towards the status quo.

Starting from the same premise of rational actors creating institutions in their favor, historical institutionalism follows the impact of past choices and the gaps in Member States' control of these processes [19] (p. 710) emphasizing a logic of path-dependence. Institutions are associated with organizations and the rules promulgated by formal organization. Historical institutionalism focuses on the asymmetries of power within the operation and development of institutions and on unintended consequences emerging in their operation [27]. In his analysis of European institutions, Pierson [28] emphasizes the gaps emerging in Member State control over the evolution of European institutions, as well as why these gaps are difficult to close and how this creates possibilities for actors other than Member States to influence the further development of integration. The focus here is not on the creation of institutions at a given point in time for fixing a political equilibrium, rather on the process that unfolds over time [28] (p. 126). What this means in short is that the current functioning of institutions cannot simply be derived from the aspirations of the original designers. In the European case, institutions such as the Commission, the ECJ or the EP are assumed to look for opportunities to increase their power while political decision-makers may face considerable constraints to control this. Gaps arise as political decision-makers face restricted time frames, while long-term institutional consequences occur as a result of relatively short-term political factors. Unanticipated consequences may result from high issue density in the EU as new regulations and shifts in Member States preferences 
in one area affect closely connected policy areas. These gaps are difficult to close as supranational actors accumulate significant political resources, institutional barriers to reform exist and individual and organizational adaptations may make policy reversal unattractive [28]. These path-dependencies and lock-ins raise the costs of policy reversal to the point where it becomes unpalatable [28] (p. 204).

Second generation institutionalists have provided a more sophisticated picture of how feedbacks may not only produce incentives for institutional continuity but may also create pressure for political change [20] (p. 128). In this perspective, although Member States remain the central actors when it comes to making grand bargains, it must be emphasized that previous decisions alter the context in which these bargains are made [28] (p. 148).

Strands of sociological institutionalism start from the analysis of the relationship between formal organizational structures and culture and emphasize that institutions shape the actors' behavior by creating a "logic of appropriateness" and stress the long-term effects of institutions. In contrast to rational-choice approaches, where institutions are assumed to be fields for strategic operation, actors are regarded as having less ability to set priorities independently from or outside of the institutional context [29] (p. 7). Institutions are thus constitutive as they shape the identity formation of their agents. Social interaction within institutions involves dynamics of learning and socialization, where learning is not reduced to acquiring new information, but also shared understanding is constructed [30]. Checkel [30] stresses three dynamics in the process of socialization: the importance of individual agency (moral entrepreneurs as agents actively seeking to persuade others); the importance of policy windows opening a possibility for entrepreneurs to turn ideas into broader normative beliefs as previously held fixed preferences break down; and the importance of social learning to create the persistence of ideas.

In conclusion then, different institutionalist approaches provide different answers to the questions of institutional formation on the one hand, but also on the operation of institutions on the other hand, and even to the question of how institutions shape the integration process. Thus, they also provide us with insights as to why integration in different policies proceeds in specific ways or how specific institutional set-ups may constrain further integration in some areas.

Constructivism, another strand theorizing about integration processes, highlights the interdependence of social norms, institutions, ideas and discourses which frame the perception of actors and thus the reality they are confronted with. This perspective suggests that interests, preferences and the perception of problems and situations are not fixed, but affected by the discursive field, in which they are constructed. Accordingly, constructivists raise questions about the "origin and reconstruction of identities, the impact of rules and norms, the role of language, and of political discourses" [31] (p. 538) which leads to them putting a different focus on institutions. Their aim is not to explain the creation of institutions, but rather to understand how institutions shape preferences and thus the behavior and even the identity of actors. They hold that European integration itself has "changed over the years" because the identity and subsequently the interests of agents has changed [31].

Discourses, which are essentially systems regulating the formation of statements, structure meaning as subjects of knowledge are created. Political discourses delineate what can be meaningfully said in a given political arena [31] (p. 164). Within discourse analysis, different approaches try to help make sense of developments within the EU: On the one hand European integration can be regarded as a struggle between different socio-economic models, focusing on the role of "polity ideas" as normative ideas for political order [32,33]. Common beliefs and values shape the development of integration and contribute to the creation of novel forms of governance [31] (p. 542). Diez, on the other hand, builds on "discursive nodal points" [34], as European governance draws together different core conceptions and links them to various meta-narratives on politics and economics. The emphasis of such approaches is placed on communicative and discursive practices, looking for the establishment of power relations through these practices as meaning is created. The use of language-referred to as "Euro-speak" by Diez [34], becomes an important focus of analysis. Unique vocabulary draws political actors together and helps in constructing a European political class [31] (p. 541). Summing up, to assess the process 
of EU integration in the field of forest policy, various discourses need to be analyzed to provide evidence as to how forest policy problems are framed, a shared meaning is developed, and actors are empowered to act by specific discursive settings.

Following this presentation of four different ways of analyzing and explaining European integration, we investigate as to whether weak forest policy integration can be explained by the fact that:

(a) strong functional implications, so-called spill-overs, created through other policy areas or political action, were missing despite continued economic integration in the EU;

(b) domestic forest politics in the Member States played a major role in EU forest policy-making processes so that Member States' determination to negotiate in the light of domestic interests hindered stronger integration attempts when major treaty reforms were on the agenda;

(c) European institutions' roles in the forest policy-making processes actually stood in the way of stronger integration attempts; or alternatively

(d) forest discourses in relation to actors' problem framing changed and the development of shared meaning as well as their empowerment to act impeded the success of integration attempts.

To do this, we rely on existing scientific literature as well as a comprehensive empirical analysis of forest-related policy documents, newsletters and legislation issued since the 1960s by the EC, the EP, the EJC and the Council. In addition, we have conducted participants observation both at the European (Standing Forestry Committee) and the domestic level (Austrian International Forest Group) and we have closely followed the development of the EU forest strategies, action programs and plans by studying document drafts in various developmental stages since the year 2002 until the present.

\section{Forest Policy from a European Integration Perspective}

\subsection{Neo-Functionalism and EU Forest Policy}

Applying neo-functional logic to the analysis of EU forest policy, we can see that during the emergence phase the main driving force for forest policy integration was the EC, which created its own place within agricultural and structural policy [1,35]. This can be regarded as functional spill-over [36], as regulations in the forestry sector were seen as a means for further diminishing trade barriers. The initiatives addressing forest matters in the 1960s were the very same as those for other non-agricultural products, which were traded internationally as wood and wood-based products, not listed in Annex II of the Treaty establishing the European Community. This was followed by a step-wise reduction and finally the abolishment of all tariff barriers, the elimination of any import quotas, and the adoption of common external customs on imported wood products (which were largely exempted from duties), and the adoption of European standards for sawn wood and logs. At that time, the EC was a net importer of wood and wood products and hence interested in preventing any kind of trade-barriers and protectionism for securing free imports and a secure timber supply for EC industries and consumers. Additionally, in the 1960s and 1970s, Community measures subsidizing investments in forestry were primarily governed by the goals of the Common Agricultural Policy (CAP) [37] (p. 13).

During the expansion phase, the EC [3,38-40] and the EP [41] again supported to a certain extend further forest policy integration. Although it must be noted, that the Council shied away from deeper institutionalization by its inaction: This is evident in the EC's answer in 1982 to an EP request: "The Commission is convinced that an effective forestry policy is needed to attain the objectives of the EEC Treaty more fully and more rapidly. ( . . ) The Commission does not intend to stop at this, but to use all the means available to it to enlarge this base" [42] (p. 14). In the late 1970s and early 1980s fires in the Mediterranean, and a growing awareness of the destruction and a loss of tropical forests around the globe, led to public pressure and consequently to pressure by the EP, which in turn requested the Commission to forward a proposal on a community policy on forests. The resulting Commission proposal was rejected by the Council of Ministers and it was not until 1986 that another attempt was 
made by the Commission to further integrate the forest policy domain. On this occasion, rejection came from the EP, which deemed that the EC proposal had not gone far enough and asked for an even more integrated common forest policy. In the same year, i.e., 1986, when the issue of "forest dieback" was high on the agenda all over Europe, measures to protect forests against atmospheric pollution [43] and fires [44] were adopted. The former was aimed at countries primarily in Central and Northern Europe, while the latter was most applicable to the warmer and drier Mediterranean countries [37].

Other non-tariff barriers to trade came into focus when tariffs and import/export quotas were eliminated, such as different national product norms (e.g., for raw wood and sawn wood) as well as environmental standards [36]. In addition to the early spill-over effects from trade policy, CAP and from regional development policy, forest-related policy making was strongly driven by perceived pressures arising from "interference" (i.e., spill-over) from other sectors policies. To counteract these spill-overs in the late 1990s, forestry actors, who until then had strongly advocated a strict implementation of the subsidiarity principle, started to argue that a "minimum extent" of a "European Forestry Policy" would be necessary to not leave the field open to competing actors from other policy domains. Those were perceived to be increasingly dominating and legislating on forestry matters at the EU level [36]. During the 1998 Austrian presidency, Member States and in particular Austria, pushed for a more systematic albeit modest approach for forest policy in the Community against the will of the EC. Interestingly given its stance in the 1980s, the latter did not want to further integrate forest policy towards the end of the 1990s. The Commission for Agriculture clearly opposed forest policy integration.

During the last development phase, many more legislative texts and policy documents that affect forest policy $[4,45]$ have been issued. Examples of this include, but are not limited to, instruments to fund forestry measures under the CAP [46] as well as those to combat trade in illegally harvested wood and products thereof [47]. Core climate instruments and initiatives include, inter alia, the EU Emission Trading Scheme [48], the Commissions Green Paper on Forest Protection and Information-Preparing Forests for Climate Change, realized in 2010 and the LULUCF instruments [49]. Closely related to climate policy are legislative initiatives in EU energy policy, where forests are prominently addressed by the Directive on the Promotion of the use of Energy from Renewable Sources [50], which has triggered additional demand for forest biomass but also intensified discussions on their sustainable production.

We can conclude then that neo-functionalism has some explanatory merit when it comes to forest policy integration ambitions with regards to the first and second policy phase. Some functional spill-over was generated by the Commission when the main funding instruments for forest policy were developed within the framework of trade and agricultural policy, creating opportunities to fund especially national afforestation measures and the construction of forest roads. Contrary to environmental policy integration (e.g., [51]), a similar process did not take place within the field of forest policy, even though more and more policy instruments that impact on forest policy and forest management were issued [52]. This can potentially be explained by the fact that the EU expanded to include new Member States with strong and diverging forest interests. While functional pressures continued to drive the need to find more comprehensive solutions for forests, national elites and stakeholder were reluctant to shift their expectations for solutions to the European level as this may have limited their possibilities to protect their own stakes. The Commission accordingly diversified its portfolio: environmental, climate and energy policies were ranked higher on the political agenda and were developed, in one or the other way, as competing with forestry objectives. As such, a political spill-over, and thus, an essential driving moment for further integration according to neo-functionalist assumptions, did not take place.

\subsection{Liberal Intergovernmentalism and Forests}

According to liberal intergovernmentalism, Member States safeguard domestic interests and try to optimize negotiation outcomes according to these interests. Seeking to analyze forest policy-making in the EU, it becomes clear that Member States nowadays emphasize, albeit to a varying degree, that forest policy lies within their responsibility as no such competences were included in the treaties 
and therefore (only) coordinative activities are needed (e.g., $[5,53,54])$. This has not always been the case however.

During the emergence phase of forest policy, the European Community had only six Member States that were not all heavily forested. Their trade balance in forest products, including wood, was negative. Despite various attempts to develop a strong forest policy at the time, Germany, Denmark and the UK consistently vetoed such an approach [41].

During the expansion phase, slowly more states became members of the European Community, including countries that are heavily forested (AT, SE, FIN). While forest policy plays a major role in Sweden, Finland and Austria this cannot necessarily be said for other acceding countries of that period. However, most EU Member States disposed of strong forest laws and strong forest administrations that were not willing to yield forest decision-making power to the EU level in most cases. The main players in forest policy-making at that time were Germany, Finland, Sweden, and Austria and to a lesser extent the United Kingdom. Although the latter did not wish for stronger integration attempts. In due course a growing number of EU level interest group federations, including forest sector associations [55], were also established and gained influence in decision-making [56,57]. The organizations included, for example, the Confederation of European Forest Owners (CEPF), European Confederation of Woodworking Industries (CEI-Bois), Confederation of European Paper Industries (CEPI), European Landowners Organisation (ELO), European Panel Federation (EPF), European Timber Trade Organisation (FEBO), European Organisation of the Sawmill Industry (OES-EOS), and the Union of European Foresters (UEF).

The importance of certain powerful Member States as regards the way their preferences shape the policy outcome is clearly seen. Nordic countries especially opposed granting more decision-making power to the EC, while biodiversity-rich Southern countries prone to forest fires were in favor of such a policy. This tension is evident in the policy instruments, adopted during the 1980s: with the inclusion of Portugal and Spain into the Community a specific Council regulation [58] establishing common measures for forestry in the Mediterranean was created. A little later, in 1986, two forest protection regulations (to fight atmospheric pollution and forest fires) were adopted and at the beginning of the 1990s afforestation measures were being reinforced in the Common Agricultural Policy.

Reacting to the developments in other fields of EU policy-making, Member States and forestry stakeholders took initiatives, such as to promote the development of non-legally binding strategies and action programs. The 'Council resolution on a forestry strategy for the European Union' of December 1998 marked a first "culmination point" of the evolving European forest policy [59]. It followed an initiative by the EP that voted for a 'resolution on the European Union's forestry strategy' in January 1997 requiring the Commission to forward a legislative proposal within two years. In 1998, the Commission presented a 'Communication on a forestry strategy for the EU' which was adopted by the Agriculture Council [60]. This council resolution was solely based on existing European legislation and also referred to international commitments of the European Community along with its Member States. Accordingly, it did not suggest any new policies. As substantial elements it identifies, for example, the goal of promoting sustainable forest management, the principle of subsidiarity, and the need to improve co-ordination with all policy areas that are relevant to the forest sector. By focusing on subsidiarity (the necessity to take decisions at the lowest possible- thus regional or national-level, with action by the Union being foreseen only in cases where Member States cannot reach the objectives) and co-ordination rather than co-operation, the critical stance of Member States towards increased Union activity becomes visible. However, many forest policy actors saw this resolution on a Forestry Strategy of the EU as a "milestone". Heads of forestry administrations and interest groups stated that they had regained leadership and had taken the wind out of the sails of those, who wanted to increase their influence on forestry [36]. Environmental interest groups, on the other hand, criticized the council resolution for a lack of transparency and participation in its elaboration and blamed the Council for failing to acknowledge the relevance of EU environmental competence but applying a one-sided production focus [61]. 
At the beginning of the more recent development phase, Austria and some other Member States attempted to bring forests into the constitution at the lowest level possible to provide a formal institutional basis for forestry policy at the EU level. However, this initiative was unsuccessful not only because the German delegates strongly opposed it due to domestic forest policy actors (Bavaria did not agree), but also because the constitutional process in the Union failed as such. Instead, Member States continued to prefer 'soft' approaches emphasizing promising terms such as "coordination" and "communication" and the principle of subsidiarity, when elaborating for example the EU Forestry Strategy and then the EU Forest Action Plan (see above). While the first Forestry Strategy presented mainly a summary of already ongoing forest-related Community activities, the second one issued in 2013 is more strategic in its approach and outlook. It was developed in response to the Green Paper "On Forest Protection and Information in the EU" [62] published in 2010 and supported by the EP, by ENGOs and Southern Member States. Forest actors lobbied for the development of a new strategy to counteract the Green Paper initiative as they had worried about potentially upcoming environmental regulations affecting forests and a loss of power [63,64].

The Commission reported back, that it had tried to establish a stronger forest policy in the sense that a legal pathway for forests was suggested to Member States, but this did not find sufficient support in the Council. This rejection is seen as being closely connected to the economic interests of large forest enterprises and forest product industries, which are perceived to usually oppose any proposal that may distort markets from their perspective via additional environmental standards and subsidies for competitors in Member States with less productive forest sectors [63]. In addition, representatives of environmental groups and administrations were reported to be "primarily interested in developing environmental policies and legislation, and not so much in a better integrated forest policy" [63]. This significant divide between environmental-conservationist, on the one hand, and forestry and commodity-oriented interests on the other hand further hinder both coordination and integration [64,65].

All those different integration attempts comply with the liberal intergovernmentalist logic that argues that domestic politics and the Member States' preferences determine the bargaining processes in the Council. They show how new members brought new interests to the table and thus changed both the bargaining processes and the outcomes. Strong interest groups at the national level determined countries' position at the European level. Despite the proposal to include forest policy in the Treaty establishing a Constitution for the European Union in 2004, this was not followed up by the Member States. However, while the liberal intergovernmentalist approach is able to explain why strong national interests in powerful Member States hindered the formation of a stronger legal basis for forest policy, it does not provide us with an explanation for a very active Commission, which found ways to incrementally develop forest policy despite the reluctance of Member States. Liberal intergovernmentalism is also not well-suited to explain how the bargaining process within the Commission affects the development of a certain policy area when various General Directorates (GD) pursue different policy ideas.

\subsection{Institutionalism and Forest Policy}

Institutionalist approaches allow us to turn towards the interaction between institutions set up by actors, the dynamics within a specific policy field brought about by the existence and activity of these institutions and how these institutions enable and constrain actors to achieve their goals. Historical institutionalists argue $[66,67]$ that these institutional choices are "sticky", and in the long run are able to shape the policy process, even if actors' preferences change.

Rather, rational choice approaches point to the problem of controlling institutions, which have been created for specific purposes (to lower transaction costs and solve problems of incomplete contracting) but then develop their own dynamics. In the area of forest policy, we see that over the past 30 years different policy areas (climate, development, trade, agriculture, environment, and energy) have increasingly impacted on forests [6] and also contributed to strengthening the role of 
the Commission. Member States on the other hand have argued for increasing the coordination of forest-related policies in the Union (e.g., [54,68,69], etc.), but have simultaneously not pressed for coordinating their own forest policies by adopting a common approach $[4,70]$ and thus securing mutual gains. This provides a key insight into why a piecemeal approach continues to dominate forest governance: while an increase in the importance of forests can be noted, an increased in the institutionalization of forest policy is absent. Instead, policy fragmentation has taken place and been augmented by forests being increasingly addressed from the perspectives of climate, nature protection, development, trade, agriculture, environment, energy policy, as well as the formulation of competing policy goals without lowering transaction costs. Having been created by the Member States as a "motor of integration", the Commission coordinated and controlled forest-related policy issues, albeit in a different form than envisaged by Member States, but as the agent (the EC) could not fully be controlled by the principals, i.e., the Member States.

Another interesting avenue for analysis is provided if one interprets institutions as rules and norms that, according to sociological institutionalism, shape the behavior and understanding of specific issues at hand. When the European Community was established, Member States decided not to include forest products (except cork) into the Annex II of the Treaty of Rome in 1957, thus excluding it from its Community policies. This said, it means that it was not possible to reach a decision by a qualified majority, but Member States could have elevated forest policy later on only unanimously [41]. When the decision rules changed in the EU from the 1990s onwards (with the Amsterdam, Nice and Lisbon treaties), and the number of heavily forested Member States increased, this has still not been as a spark to breathe life into a common forest policy. Perhaps this is because the Commission never explicitly proposed a council regulation (only a minor policy instrument-a council resolution was proposed (see [40,71]) between 1959 and 1978. The Commission proposal of a council directive [38,39] did also never find systematic support. Instead financial support was granted to national forestry activities [72,73], administrative structures [74,75] such as the Standing Forestry Committee were established, and a number of other forest-related EU level committees were founded over the years, each with specific tasks and functions connected to forest policy (for example, Civil Dialogue Group on Forestry and Cork, Expert Group on Forest-based Industries and Sectorally Related Issues, the etc.). Well before, other administrative instruments served the Commission, such as the Heads of Forest Service Group (COFOR) and the Heads of Forestry Research Group (REFOR [76]).

Furthermore, legislation was continuously enacted in the areas of trade, climate, environment, development, and plant health as well as other forest-related areas. [52,77]. These financial, structural and legislative means have over the years reinforced forest policy and contributed to its "indirect institutionalization" within the Union, while the safeguarding of the multiple roles of forests became a dominant norm [54,69], albeit weakly institutionalized. A certain "logic of appropriateness"—as emphasized by sociological institutionalism—seems clearly at play as Member States as well as EU institutions since 1993 have continuously committed themselves to sustainable forest management (SFM) within the Union and in Europe at large [78]. It is not only continuously referred to in EU and national documents, but now has become the norm when referring to how forest management has to be undertaken and understood. A number of related policy instruments issued by other institutions (e.g., certification schemes, criteria and indicator processes (see [79]) have been established since. While SFM does inscribe the business as a usual model to forestry, environmental actors have contested this to a certain extent. In conclusion to this section then, institutionalism has proven to have some merit when explaining forest policy integration, but different institutional approaches lend themselves to explain different phenomena.

\subsection{Constructivism and Changing Forest Discourses}

Following a constructivist account, it is important to understand how the meaning making process within the Union has played out in relation to forest policy-making, how problem perceptions were constructed and to examine underlying assumptions of decision-making as situations are not to be 
understood as fixed. During the first forestry conference [80] organized by the EC in June 1959 it was argued that the Community should "implement a common forestry policy in all Member States in order to conserve, improve, and increase the value of and possibly extend woodlands in the Community and associated countries" [80]. Clearly wood production and afforestation (including afforestation of agricultural land not in use) were seen as the central aims of forest policy at that time. As early as 1959, the Commission was also asked to set up a Standing Committee on Forestry within its structures and to create a forestry department within the General Directorate of Agriculture, thus creating an institutional arrangement for a new policy field. In 1960, the Commission reiterated the call for a common forestry policy [1]. This was further clarified in 1964, when it was stated that: “ . . there can be no question of planning a common policy for timber, which is not listed in Annex II of the Treaty, such a policy (common policy on forestry affairs) could be contemplated as part of policy on structures, because this would mean improving the conditions governing land profitability, the main factor in agricultural production" [68]. This view is understandable in perspective as at that time forestry was largely understood to be a part of agricultural and structural policy. An additional point to keep in mind, is that a strong trade deficit in forest products can be understood as a key trigger for this call [1].

The afforestation of land was seen as a means to increase land productivity and thus to decrease the trade deficit [81]. Various policy instruments issued at the time point in this direction. For example, the 1st environmental action program [82] included a proposal for a directive on land afforestation. The declaration on the first environmental action program of the Council in 1973 also clearly points towards such a production discourse as it pressed for afforestation of unproductive areas. Policy instruments agreed on earlier affirm this (e.g., Council Directive 66/404/EEC on the marketing of forest reproductive material and Council Directive 68/89/EEC concerning the classification of wood in the rough, see $[83,84])$. In February 1974, the Commission forwarded a proposal for a directive on measures for forestry and a revised proposal was submitted in 1975 [39]. In both documents, however, forestry was not only connected to land afforestation and woodland improvement but also linked to ideas centering on the conservation of fauna and flora, preserving beautiful landscapes and soil protection. This was reiterated in the opinion of the Economic and Social Committee (ESC) in 1974 where, in its newsletter [85], the EC explicitly stated that recreation does not conflict with timber production or environmental preservation. Thus, by the mid-1970s, the Commission had slightly changed and realigned its outlook towards an enlarged set of forest policy goals [86].

In 1978, the EC proposed a Council Resolution [40] explicitly suggesting better coordination of national forest policies to achieve increased timber production, environmental conservation and public access to forests for recreation. This communication can be understood as the most explicit one in terms of taking a multiple purpose approach at that time, incorporating measures other than land conversion and wood production, as it also suggested creating measures for conserving and protecting natural environments, public access for recreation, as well as wildlife management, this communication also referred to forest policy instruments (e.g., in terms of organization, legislation, taxation, financial means, forest statistics). It suggested applying common criteria to all Member States, to consult with interest groups, and to encourage the creation of a positive forest image through public relations. Again, a more institutional approach was proposed (creating a separate forestry committee [40]) to the Council, however the EP and the ESC disagreed with the Commission [87]. Both the EP and ESC envisaged a common forest policy based on the functioning of the common market and in addition to what has been described already, they indicated the lack of a joint forestry policy as the real problem.

By the end of the 1970s, the protection discourse along with the production discourse had become entrenched in other policy instruments, e.g., in council regulations establishing common measures for forestry in certain Mediterranean zones and for the stimulation of agricultural development in the less suitable areas of the west of Ireland (see $[58,88]$ ).

In the early 1980s, the protection discourse became even more robust. Proposals for regulations on air pollution and forest fires were issued accompanied by afforestation regulations for the Mediterranean region. The main problem description was broadened to protecting forests from 
acid rain, storm damage and pests. The fragmented ownership of forests, as well as the trade deficit in forestry products and forest fires, were also assessed as problematic for European forestry $[32,89]$. In 1986, the Commission explicitly stated that the main functions of Europe's forests were threefold: production of raw material, maintenance of the ecological balance and as an area of recreational activities [3]. The problem description however still referred to productivity (the perceived need for extending forest areas and reducing the forestry related trade deficit), protection (action against air pollution and forest fires), but also arresting the loss of tropical forests. In the same year, the Commission for the first time also referred to forestry problems outside of the Community, thus extending its scope. This was the moment, when the Commission claimed in its complementary memorandum to its Discussion Paper on the Community Action in the Forestry Sector [85] (p. 88f) that-despite arguments in previous statements—, that a missing legal basis for actions on forestry is fallacious as "no legal obstacle or interdict to prevent the Community from taking action in this area" could be ascertained. The Commission explained further that inactivity by the Council can be explained by the fact that no appropriate forum for ministers in charge of forestry is available. Thus, it used an institutionally based line of reasoning to explain the European level inaction. Further proposals for the setting up a standing forestry committee (in 1983 a committee on Community policy regarding forestry and forestry-based industries was established), creating reports on forestry situations and a mid-term Community forestry program among other things were suggested to further institutionalize forestry issues (see also [90]). However, this seems to have been insufficient for the EP, which maintained its call for a common forestry policy [91] (p. 74).

At the beginning of the 1990s, the EP even published a handbook on the "Common Forestry Policy" [41] and commissioned a related study. Both were followed up by its first own initiative (a new right granted due to the treaty changes) which led to the parliament asking the Commission to forward a legislative proposal on forestry. In its so-called "Thomas Report" [92] the EP reiterated its call to present a legislative proposal on a European forestry strategy and the EP resolution that followed clearly called for "multiple use of forestry" for the first time. This focus on the multi-functional role of forests was further emphasized by the Council in its resolution on a forestry strategy that the Commission published in 1998 [69]. The threats identified for forestry therein can be summarized as: deforestation, air pollution, forest fires and climate change.

Following an ECJ ruling in 1999, forest protection was based on Article 175 of the Treaty, giving priority to the General Directorate of Environment and further empowering the protection discourse [6] (p. 31). Three years later in 2002, the Inter-Service Group on Forestry was established to support the coordination of forest-related measures between Commission General Directorates. In 1999, the Commission also published a communication [93] on the state of the competitiveness of the forest industries pointing out that the cost of wood, energy, chemicals, labor and transportation is higher when compared to competing regions and that the impact on research and development (R\&D), innovation, EU legislation and administrative factors are considerable. In the years that followed, the ESC and the EP repeatedly stressed the importance of enhancing coordination on forestry matters. In 2006, the EP once again called [94] for the creation of a separate legal basis for forests in the EU treaties. In the same year, the Commission also published an EU Forest Action Plan [95] that built on its forestry strategy [69] and was supposed to serve as a coordination tool for forest related activities and policies across the Union. Coordination, which in the 1960s meant coordinating the national forest policies of six members, now, involved coordinating forest-related policies throughout a greatly expanded Union. Additionally, the Green Paper "on forest protection and information" [62] set out the challenges for forests from a multiple purpose perspective while aiming at collecting citizens' and stakeholders' views on the potential impact of climate change on forests. In 2010, a new law [47] on preventing illegal timber and timber products from entering the common market was published. This law is remarkable in that it is not only part of the EU's FLEGT Action Plan [96], but also finally completes the EU's external take on forest policy. The latest Commission communication on a new EU Forest Strategy [54] and its Multi-Annual Implementation Plan [97] both again strongly promote the multiple 
purpose discourse, which was already so prominent in earlier documents. This multiple purpose discourse of forests also links to the fact that presently many more forest-related legal instruments and activities are being set in the EU context, which had to be taken care of by the current Forest Strategy. While the first Forest Strategy was more descriptive in nature, the second one was slightly more strategic in that it points out guiding principles and 2020 forest objectives.

Briefly summarizing the above then, the constructivist approach allows us to take a different viewpoint on how the relatively weak forest policy institutionalization can be understood. The analysis revealed three major discourses upon which forest policy in the EU has developed over time: the production discourse (from 1958 to the mid-1970s), an overlap between a production and a protection discourse (from circa the mid-1970s until the end of the 1990s) and the dominance of the multiple purpose discourse (from the end of 1990s until the present day), where different policy goals are to be met simultaneously. This shift in discourses over the three developmental phases is also confirmed by legal analysis [6] that shows over time different basis for legal action were employed to support the EU's revised focus and efforts, shifting from agriculture and trade to environment and to biodiversity, climate change and energy.

\section{Conclusions: Why a Multi-Theory Analysis Is More than the Sum of Individual Perspectives on EU Forest Institutionalization}

This article started out by asking how the weak institutionalization of forest policy can be explained and understood in the EU. Empirically dividing the development of EU forest policy into three policy periods (emergence-1958 to the 1960s, expansion-1970 to the late 1990s, establishment-late 1990s to now) we showed that, to a certain extent, all European integration theories have some merits for analytical purposes. However, none of the employed integration theories alone can explain the broader development of forest policy in the EU in all its relevant aspects. None alone can substantially explain why it has developed only incrementally and why it has only been weakly institutionalized. However, each approach holds some explanatory value for specific aspects of the development of forest policy in the EU, and by combining them we are able to get a clearer, multi-dimensional picture of driving factors and constraints.

During the first period of forest policy making, we find valuable explanations by applying a neo-functionalist approach. We see a functional spill-over, especially from agricultural policy and trade, creating the necessity for forest-related regulations. Nevertheless, although Member States recognized the need for better co-ordination and for some issues actually put forward common regulations, the shift of expectations for common policies to the supranational level remained limited. This situation has been further complicated over time with increasingly diverging interests being introduced to the mix after the enlargement of the Communities. In the second and third phase, we see that although forests remained high on the EC's agenda, no common ground was found between Member States. Important interest groups within Member States also hampered a shift of competences in forest policy to the European level. This starkly contrasts with other areas such as environmental policy, climate change and energy, which have been repeatedly strengthened through consecutive treaty revisions.

To get a better idea on the effects of these events on forest policy, liberal intergovernmentalism has however limited explanatory value. It is a useful tool to explain why certain things did not happen but is not well-suited to explaining what did happen. In order to understand the role of the Commission as a driving force on forest-related issues, as well as understand the increasing patchwork of regulation, the piecemeal approach and the emergence of contradicting policy goals in relation to forests, effective analysis requires one to turn to different institutionalist approaches. From an institutional perspective in both the expansion and the establishment phase, the Commission was able to assert its competences, although mostly in the forest-related domains such as e.g., nature protection. As institutional structures were built and financial means were created to support national forest policy, an indirect institutionalization of forest policy continued, even without a definite legal basis for forests in the treaties. Both the EC and the EP vocally supported the idea of stronger institutionalization 
and kept it on the agenda, despite the rejection of further institutionalization by the Member States. Nevertheless, without the support of the Member States this institutionalization remained weak.

What has not been answered so far by these approaches (neo-functionalism, liberal intergovernmentalism and institutionalism) is, why at different times, varying emphasis was put on different aspects of forests for common approaches. Here, the constructivist approach is the most helpful tool that can be employed. The analysis shows that the focus of discourses changed over time: Between 1958 and the mid-1970s the forest production discourse was dominant, while in the following period until the 1990s the focus was on forest protection and later changed towards the multiple-purpose discourse on forests. These discourses were somewhat double-edged as they proved to be enabling factors for some actors, but constraining for others. They have also proven to be a lasting impediment to the development of a shared meaning regarding forests and recognition of the need to strongly institutionalize forest policy at the EU level. In essence, this has resulted in the dominant discourses of the time being the key driver for specific aspects of forest-related issues being regulated. Thus, constructivist approaches allow us to understand a further-and rather startling - constraint being placed on efforts to increase the institutionalization of forest policy at the moment: the multi-purpose discourse on forests, guided by an ever more comprehensive understanding of the various roles of forests, actually impedes further institutionalization as issues such as climate change, energy, environmental protection, and trade put forth their own rationale of regulation and establish conflicting goals, making a common policy on forests even more unlikely.

The foregoing thus clearly demonstrates that none of the theoretical approaches is fully able to explain the current state of play, but each weighs in with its own explanatory value and contributes to our understanding of why and how the current form of institutionalization of forest policy at the EU level has come to be. As Heipertz and Verdun [98] have shown-albeit for the area of the Monetary Union-only an eclectically constructed combination of different approaches provides satisfying explanations to what have been persistently opaque problems. Each approach explains a part or aspect of the puzzle, but together they form a picture. This helps us to broaden and deepen our understanding of European integration phenomena [98]. While neo-functionalism is able to explain the pressures resulting from one policy field for further integration into another policy field and thus also shapes policy preferences of domestic actors and in consequence Member States' interests, liberal intergovernmentalism provides us with tools to understand how these interests then control the integration process (and strength of institutionalization) as such. Nevertheless, both grand theories have their weaknesses in explaining how institutions shape day-to-day policy formulation in specific policy areas. This inability extends to also being blindsided to how not only interests, but also different problem framings, the identities of actors themselves and dominant narratives form the preferences of actors. This highlights the necessity for scholars of European studies to work across a broader theoretical spectrum, as only this will allow light to be shone on blind spots in empirical investigation over longer time periods.

Author Contributions: All authors conceived, designed and wrote the manuscript together; the first author performed the data collection and analysis supported by the other authors. The second author performed the description of the European integration theories supported by the other authors.

Funding: The authors have received no research grants.

Acknowledgments: The authors would like to explicitly thank the three reviewers for their insightful comments that helped greatly to improve the paper. In addition, the authors wish to thank Ian Silver for his very competent English language editing. Finally, the authors would like to acknowledge the support of the BOKU Vienna Open Access Publishing Fund.

Conflicts of Interest: The authors declare that they have no conflict of interest. 


\section{References}

1. European Commission. Proposals for the working out and putting into effect of the common agricultural policy in application of Article 43 of the Treaty establishing the European Economic Community. In COM (1960) 105 Final; European Commission: Brussels, Belgium, 1960.

2. European Parliament. Resolution embodying the opinion of the European Parliament on the communication from the Commission of the European Communities to the Council concerning forestry policy in the European Community. Official Journal of the European Union 140, 5 July 1979.

3. Commission of the European Communities. Discussion Paper on Community Action in the Forestry Sector. In COM (1985) 792 Final; European Commission: Brussels, Belgium, 1985.

4. Aggestam, F.; Pülzl, H. Coordinating the Uncoordinated: The EU Forest Strategy. Forests 2018, 9, 125. [CrossRef]

5. Pülzl, H.; Hogl, K.; Kleinschmit, D.; Wydra, D.; Arts, B.; Mayer, P.; Palahi, M.; Winkel, G.; Wolfslehner, B. (Eds.) European Forest Governance: Issues at State and the Way Forward; What Science Can Tell Us 2; European Forestry Institute: Joensuu, Finland, 2013; p. 100. ISBN 978-952-5980-02-8.

6. Wydra, D. The legal context of European Forest Policy-Making. In European Forest Governance: Issues at State and the Way Forward; Pülzl, H., Hogl, K., Kleinschmit, D., Wydra, D., Arts, B., Mayer, P., Palahi, M., Winkel, G., Wolfslehner, B., Eds.; What Science Can Tell Us 2; EFI: Joensuu, Finland, 2013; pp. 29-36. ISBN 978-952-5980-02-8.

7. Haas, E.B. The Uniting of Europe: Political, Social and Economic Forces 1950-57, 3rd ed.; Stanford University Press: Stanford, CA, USA, 1958/2004.

8. Haas, E.B. Beyond the Nation State: Functionalism and International Organization; Stanford University Press: Stanford, CA, USA, 1964; 595p.

9. Rosamond, B. Theories of European Integration; Macmillan: London, UK, 2000; p. 232. ISBN 100312231202.

10. Schmitter, P.C. Neo-Neo-Functionalism. In European Integration Theory, 1st ed.; Wiener, A., Diez, T., Eds.; Oxford University Press: Oxford, UK, 2004; pp. 45-75.

11. Niemann, A.; Schmitter, P.C. Neofunctionalism. In European Integration Theory, 2nd ed.; Wiener, A., Diez, T., Eds.; Oxford University Press: Oxford, UK, 2009; pp. 45-66.

12. Rosamond, B. The uniting of Europe and the foundation of EU studies: Revisiting the neofunctionalism of Ernst B. Haas. J. Eur. Public Policy 2005, 12, 237-254. [CrossRef]

13. Lindberg, L.N. Political Dynamics of European Economic Integration; Princeton University Press: Stanford, CA, USA, 1963, 0804701679; ISBN 100804701679.

14. Schmitter, P.C. A Revised Theory of Regional Integration. Int. Organ. 1970, 24, 836-868. [CrossRef]

15. Moravcsik, A. Preferences and power in the European Community. A liberal intergovernmentalist approach. J. Common Mark. Stud. 1993, 31, 473-524. [CrossRef]

16. Moravcsik, A. The Choice for Europe: Social Purpose and State Power from Messina to Maastricht; Cornell University Press: Ithaca, NJ, USA, 1998; 528p, ISBN -10.

17. Moravcik, A.; Schimmelfennig, F. Liberal Intergovernmentalism. In European Integration Theory, 2nd ed.; Wiener, A., Diez, T., Eds.; Oxford University Press: Oxford, UK, 2009; pp. 67-87.

18. Keohane, R.O. After Hegemony: Cooperation and Discord in the World Political Economy; Princeton University Press: Stanford, CA, USA, 1984; 320p.

19. Laffan, B. The European Union polity: A union of regulative, normative and cognitive pillars. J. Eur. Public Policy 2001, 8, 709-727. [CrossRef]

20. Pollack, M.A. The New Institutionalisms and European Integration. In European Integration Theory, 2nd ed.; Wiener, A., Diez, T., Eds.; Oxford University Press: Oxford, UK, 2009; pp. 125-143.

21. Jupille, J.; Caporaso, J.A. Institutionalism and the European Union: Beyond international relations and comparative politics. Annu. Rev. Political Sci. 1999, 2, 429-444. [CrossRef]

22. Shepsle, K.A. Rational Choice Institutionalism. In Oxford Handbook of Political Institutions; Binder, S., Rhodes, R., Rockman, B., Eds.; Oxford University Press: Oxford, UK, 2006.

23. Pollack, M.A. Delegation, agency, and agenda setting in the European Community. Int. Organ. 1997, 51, 99-134. [CrossRef]

24. Tsebelis, G.; Garrett, G. The Institutional Foundations of Intergovernmentalism and Supranationalism in the European Union. Int. Organ. 2001, 55, 357-390. [CrossRef] 
25. Kassim, H.; Menon, A. The Principal-Agent Approach and the Study of the European Union: Promise Unfulfilled? J. Eur. Public Policy 2003, 10, 121-139.

26. Garrett, G. International cooperation and institutional choice: The European Community's internal market. Int. Organ. 1992, 46, 533-560. [CrossRef]

27. Hall, P.; Taylor, R. Political Science and the Three New Institutionalisms. Political Stud. 1996, 44, $936-957$. [CrossRef]

28. Pierson, P. The Path to European Integration: A Historical Institutionalist Analysis. Compar. Political Stud. 1996, 29, 123-163. [CrossRef]

29. Aspinwall, M.D.; Schneider, G. Same menu, separate tables: The institutionalist turn in political science and the study of European integration. Eur. J. Political Res. 2000, 38, 1-36. [CrossRef]

30. Checkel, J.T. Norms Institutions, and National Identity in Contemporary Europe. Int. Stud. Q. 1999, 43, 84-114. [CrossRef]

31. Christiansen, T.; Jorgensen, K.E.; Wiener, A. The social construction of Europe. J. Eur. Public Policy 1999, 6, 528-544. [CrossRef]

32. Waever, O. Discursive Approaches. In European Integration Theory, 2nd ed.; Wiener, A., Diez, T., Eds.; Oxford University Press: Oxford, UK, 2009; pp. 163-180.

33. Jachtenfuchs, M.; Diez, T.; Jung, S. Which Europe? Conflicting Models of a Legitimate European Political Order. Eur. J. Int. Relations 1998, 4, 409-446. [CrossRef]

34. Diez, T. Europe as a Discursive Battle Ground. Discourse Analysis and European Integration Studies. Cooperation Confl. 2001, 36, 5-38. [CrossRef]

35. European Commission. Directorate General for Agriculture of the EEC Commission. In Newsletter of the Common Agricultural Policy; European Commission: Brussels, Belgium, 1964.

36. Hogl, K. Europäisierung der Forstpolitik? Thesen zu Auswirkungen auf das Akteursgefüge am Beispiel Österreichs. In Staatsforstverwaltungen und Europäische Union. Erfahrungen und Zukunftsstrategien im europäischen Vergleich; Krott, M., Meyer, W., Eds.; Europaforum Forstverwaltung 9, Institut für Forstpolitik und Naturschutz, Universität Göttingen: Göttingen, Germany, 2001; pp. 187-210.

37. Pettenella, D. EU Forest Policy and its impacts on the Mediterranean countries. Medit 1994, 3, 11-15.

38. Commission of the European Communities. Proposal for a Council Directive concerning forestry measures. In COM (1974) 170 Final; European Commission: Brussels, Belgium, 1974.

39. Commission of the European Communities. Revised proposal for a Council Directive concerning forestry measures. In COM (1975) 188 Final; European Commission: Brussels, Belgium, 1974.

40. Commission of the European Communities. Proposal for a Council resolution concerning the objectives and principles of forestry policy. In COM (1978) 621 Final; European Commission: Brussels, Belgium, 1978; Official Journal of the European Union 301, 15 December 1978, pp. 8-11.

41. European Parliament. Handbook on the forestry policy of the European Community. In Research and Documentation Papers; Office for Official Publications of the European Communities: Luxembourg, 1992; ISBN 92-823-0345-4.

42. European Parliament. Written Questions with Answer. OJ C 167 5.07.1982. Available online: https: / / eur-lex.europa.eu/legal-content/EN/TXT/PDF/?uri=OJ:C:1982:167:FULL\&from=EN (accessed on 1 September 2017).

43. Council of the European Communities. Council Regulation (EEC) No 3528/86 of 17 November 1986 on the protection of the Community's forests against atmospheric pollution. Official Journal of the European Union 326, 21 November 1986; pp. 2-4.

44. Council of the European Communities. Council Regulation (EEC) No 3529/86 of 17 November 1986 on protection of the Community's forests against fire. Official Journal of the European Union 326, 21 November 1986; pp. 5-7.

45. Rivera Leon, L.; Bougas, K.; Aggestam, F.; Pülzl, H.; Zoboli, E.; Ravet, J.; Griniece, E.; Vermeer, J.; Maroulis, N.; Ettwein, F.; et al. An Assessment of the Cumulative Cost Impact of Specified EU Legislation and Policies on the EU Forest-Based Industries; DG GROW: Brussels, Belgium, 2016.

46. The European Parliament and the Council of the European Union. Regulation (EU) No 1305/2013 of the European Parliament and of the Council of 17 December 2013 on support for rural development by the European Agricultural Fund for Rural Development (EAFRD) and repealing Council Regulation (EC) No 1698/2005. Official Journal of the European Union 347, 20 December 2013; pp. 487-548. 
47. The European Parliament and the Council of the European Union. Regulation (EU) No 995/2010 of the European Parliament and of the Council of 20 October 2010 laying down the obligations of operators who place timber and timber products on the market Text with EEA relevance. Official Journal of the European Union 295, 12 November 2010; pp. 23-34.

48. Directive 2003/87/EC of the European Parliament and of the Council of 13 October 2003 establishing a scheme for greenhouse gas emission allowance trading within the Community and amending Council Directive 96/61/EC (Text with EEA relevance). Official Journal of the European Union L 275, 25 October 2003; p. 32.

49. The European Parliament and the Council of the European Union. Regulation (EU) 2018/841 of the European Parliament and of the Council of 30 May 2018 on the inclusion of greenhouse gas emissions and removals from land use, land use change and forestry in the 2030 climate and energy framework, and amending Regulation (EU) No 525/2013 and Decision No 529/2013/EU (Text with EEA relevance) PE/68/2017/REV/1. Official Journal of the European Union 156, 19 June 2018; pp. 1-25.

50. The European Parliament and the Council of the European Union. Directive 2009/28/EC of the European Parliament and of the Council of 23 April 2009 on the promotion of the use of energy from renewable sources and amending and subsequently repealing Directives 2001/77/EC and 2003/30/EC (Text with EEA relevance). Official Journal of the European Union 140, 5 June 2009; pp. 16-62.

51. Lenschow, A. Studying EU environmental policy. In Environmental Policy in the EU. Actors, Institutions and Processes, 3rd ed.; Jordan, A., Adelle, C., Eds.; Routledge: Oxon, UK, 2013; pp. 49-72. ISBN 13 978-1-84971-468-6.

52. Pülzl, H.; Wydra, D. Waldrelevante Politiken und GEsetze in der Europäischen Union-Eine Evaluierung; Projektendbericht, Universität für Bodenkultur Wien: Vienna, Austria, 2014.

53. European Parliament. European Parliament Resolution of 28 April 2015 on A new EU Forest Strategy: For forests and the forest-based sector (2014/2223(INI)). Official Journal of the European Union 346, 21 September 2016; pp. 17-26.

54. European Commission. A new EU Forest Strategy: For forests and the forest-based sector. In COM (2013) 659 Final; European Commission: Brussels, Belgium, 2013.

55. Hogl, K. How to Co-ordinate the Non-Intergrated: Development and Recent Perspectives of European Union Forest Policy. In Quo Vadis, Forestry? Zbigniew, S., Ed.; Instytut Badawczy Lesnictwa: Sekocin Stary, Poland, 2007; pp. 18-32.

56. Hey, C.; Brendle, U. Umweltverbände und EG: Strategien, Politische Kulturen und Organisationsformen; Westdeutscher Verlag: Opladen, 1994; ISBN -3531126199.

57. Weber, N.; Christopherson, T. The influence of non-governmental organisations on the creation of Natura 2000 during the European policy process. For. Policy Econ. 2002, 4, 1-12. [CrossRef]

58. Council of the European Communities. Council Regulation (EEC) No 269/79 of 6 February 1979 establishing a common measure for forestry in certain Mediterranean zones of the Community. Official Journal of the European Union 38, 14 February 1979; pp. 1-5.

59. Hogl, K. The Austrian domestic forest policy community in change? Impacts of the globalisation and Europeanisation of forest politics. For. Policy Econ. 2000, 1, 3-13. [CrossRef]

60. Council. Council Resolution of 15 December 1998 on a Forestry Strategy for the European Union. Official Journal of the European Union 56/1, 26 February 1999.

61. Greenpeace, FERN, WWF. Preliminary NGO Comments Regarding the Draft EU Forest Strategy; Greenpeace European Unit: Brussels, Belgium, 1998.

62. European Commission. Green Paper on Forest Protection and Information in the EU. Preparing forests for climate change. In COM (2010) 0066 Final; European Commission: Brussels, Belgium, 2010.

63. Winkel, G.; Sotirov, M. Whose integration is this? European forest policy between the gospel of coordination, institutional competition, and a new spirit of integration. Environ. Plan. C Gov. Policy 2016, 34, 496-514. [CrossRef]

64. Edwards, P.; Kleinschmit, D. Towards a European forest policy-Conflicting courses. For. Policy Econ. 2013, 33, 87-93. [CrossRef] 
65. Winkel, G.; Kaphengst, T.; Herbert, S.; Robaey, Z.; Rosenkranz, L.; Sotirov, M. EU Policy Options for the Protection of European Forests Against Harmful Impacts. Final Report to the Tender: ENV.B.1/ETU/2008/0049: OJ 2008/S 112-149606. 2009. Available online: http:/ / ec.europa.eu/environment/ forests/pdf/ifp_ecologic_report.pdf (accessed on 1 September 2017).

66. Thelen, K. Historical Institutionalism in Comparative Politics. Annu. Rev. Political Sci. 1999, 2, 369-404. [CrossRef]

67. Pierson, P. Politics in Time: History, Institutions and Social Analysis; Princeton University Press: Princeton, NJ, USA, 2004.

68. Official Spokesman of the Commission. Co-Ordination of National Forestry Policies; Information memo. P-13/64; European Economic Community: Brussels, Belgium, 1964.

69. European Commission. Communication from the Commission to the Council and the European Parliament on a Forestry Strategy for the European Union. In COM (1998) 649 Final; European Commission: Brussels, Belgium, 1998.

70. Pülzl, H.; Hogl, K. Forest Governance in Europe. In European Forest Governance: Issues at State and the Way Forward; Pülzl, H., Hogl, K., Kleinschmit, D., Wydra, D., Arts, B., Mayer, P., Palahi, M., Winkel, G., Wolfslehner, B., Eds.; European Forest Institute: Joensuu, Finland, 2013; pp. 11-18. ISBN -978-952-5980-02-8.

71. Commission of the European Communities. Proposal for a Council Resolution concerning objectives and lines of actions for Community policy regarding forestry and forest-based industries. In COM (1983) 222 Final; European Commission: Brussels, Belgium, 1983.

72. Pelli, P.; Aggestam, F.; Weiss, G.; Inhaizer, H.; Heikkinen, J.; Keenleyside, C.; Gantioler, S.; Boglio, D.; Poláková, J. Ex-Post Evaluation of the EU Forest Action Plan; European Forestry Institute: Joensuu, Finland, 2012.

73. Winkel, G.; Aggestam, F.; Sotirov, M.; Weiss, G. In European Forest Governance: Issues at State and the Way Forward; Pülzl, H., Hogl, K., Kleinschmit, D., Wydra, D., Arts, B., Mayer, P., Palahi, M., Winkel, G., Wolfslehner, B., Eds.; What Science Can Tell Us 2; EFI: Joensuu, Finland, 2013; pp. 52-63. ISBN -978-952-5980-02-8.

74. The Council of the European Communities. 89/367/EEC: Council Decision of 29 May 1989 setting up a Standing Forestry Committee. Official Journal of the European Union 165, 15 June 1989; pp. 14-15.

75. Commission of the European Communities. Commission Decisions of 11 May 1983 setting up a Committee on Community Policy regarding Forestry and Forestry-based Industries. 83/247/EEC. Official Journal of the European Union 137/32, 26 May 1983.

76. European Community. Europe's green mantle. Heritage and future of our forests. In Newsletter on the Common Agricultural Policy; Office for Official Publications of the European Communities: Luxembourg, 1984.

77. Aggestam, F.; Winkel, G.; Pülzl, H.; Sotirov, M. The EU Policy Framework. In Towards a Sustainable European Forest-Based Bioeconomy-Assessment and the Way Forward; EFI Series: What Science Can Tell Us 8; Winkel, G., Ed.; European Forest Institute: Joensuu, Finland, 2017; pp. 19-35.

78. Pülzl, H.; Mayer, P. Assessment of the Achievements and Added Value of the Forest Europe Process. 2015, p. 17. Available online: https://www.foresteurope.org/sites/default/files/Assessment-of-theachievements_FINAL.pdf (accessed on 1 August 2018).

79. Linser, S.; Wolfslehner, B.; Asmar, F.; Bridge, S.R.; Guadalupe, V.; Gritten, D.; Jafari, M.; Johnson, S.; Laclau, P.; Robertson, G. 25 years of criteria and indicators for sustainable forest management: Why some intergovernmental C\&I processes flourished while others faded. Forests 2018, 9, 515. [CrossRef]

80. Mantel, K. Die erste Europäische Forstkonferenz in Brüssel vom 9.bis 11.6.1959. Der For. Und Holzwirt 1959, 14, 269-276.

81. European Commission. Directorate General for Agriculture of the EEC Commission. In Le Boisement des Terres Marginales. Informations Internes sur l'Agriculture. 5221/VI/64-F; European Commission: Brussels, Belgium, 1964.

82. Council of the European Communities. Declaration of the Council of the European Communities and of the Representatives of the Government of the Member States meeting in Council of 22 November 1973 on the Program of Action of the European Communities on the Environment. Official Journal of the European Union 111/1, 22 November 1973; pp. 1-54.

83. Council of the European Economic Community. Council Directive 66/404/EEC of 14 June 1966 on the marketing of forest reproductive material. Official Journal of the European Union 125, 11 July 1966. 
84. Council of the European Communities. Council Directive 68/89/EEC of 23 January 1968 on the approximation of the laws of the Member States concerning the classification of wood in the rough. Official Journal of the European Union 32, 6 February 1968.

85. Commission of the European Communities. Complementary Memorandum to the Discussion Paper on the Community Action in the Forestry Sector; European Commission: Brussels, Belgium, 1985.

86. European Commission. Directorate General for Agriculture of the EEC Commission. Forestry's contribution towards a progressive land-use policy in the Community. In Newsletter of the Common Agricultural Policy; European Commission: Brussels, Belgium, 1974.

87. Kommission der Europäischen Gemeinschaft. Die Forstpolitik der Europäischen Gemeinschaft. Bulletin der Europäischen Gemeinschaften Beilage 3/79; Amt für amtliche Veröffentlichungen der Europäischen Gemeinschaften: Luxemburg, 1979; p. 51. ISBN 92-825-1342-4.

88. Council of the European Communities. Council Regulation (EEC) No 1820/80 for the stimulation of agricultural development in the less-favoured areas of the west of Ireland. Official Journal of the European Union 180, 14 July 1980; pp. 1-8.

89. European Parliament. Resolution on Community forestry policy. Official Journal of the European Union 307/123, 14 October 1983; p. 123.

90. Commission of the European Communities. Community Strategy and Action programme for the forestry sector. In COM (1988) 255 Final; European Commission: Brussels, Belgium, 1988.

91. European Parliament. Resolution Community action in the forestry sector. Official Journal of the European Union 297, 23 October 1986.

92. European Parliament. Report on the European Union's forestry strategy, Committee on Agriculture and Rural Development, Rapporteur: David E Thomas, adopted 12th December 1996, PE 213.578/fin. Available online: http://www.europarl.europa.eu/sides/getDoc.do?language=EN\&pubRef=- //EP / /TEXT+REPORT+A4-1996-0414+0+DOC+XML+V0/ /EN (accessed on 29 August 2018).

93. European Commission. Communication from the Commission to the Council, the European Parliament, the Economic and Social Committee and the Committee of the Regions - The state of the competitiveness of the EU forest-based and related industries. In COM (1999) 457 Final; European Commission: Brussels, Belgium, 1999.

94. European Parliament. Report on the implementation of a European Union forestry strategy (2005/2054(INI)), Committee on Agriculture and Rural Development Rapporteur: Heinz Kindermann, 31.1.2006, A6-0015/2006. Available online: http://www.europarl.europa.eu/sides/getDoc.do?pubRef=- //EP/ /NONSGML+REPORT+A6-2006-0015+0+DOC+PDF+V0/ /EN (accessed on 29 August 2018).

95. European Commission. Communication from the Commission to the Council and the European Parliament on an EU Forest Action Plan. In COM (2006) 302 Final; European Commission: Brussels, Belgium, 2006.

96. European Commission. Communication from the Commission to the Council, the European Parliament. Forest Law Enforcement, Governance and Trade (FLEGT). Proposal for an EU Action Plan. In COM (2003) 251 Final; European Commission: Brussels, Belgium, 2003.

97. European Commission. Multi-annual implementation plan of the new EU forest strategy. In SWD (2015) 164 Final; European Commission: Brussels, Belgium, 2015.

98. Heipertz, M.; Verdun, A. The Stability and Growth Pact-Theorizing a Case in European Integration. J. Common Market Stud. 2005, 43, 985-1008. [CrossRef]

(C) 2018 by the authors. Licensee MDPI, Basel, Switzerland. This article is an open access article distributed under the terms and conditions of the Creative Commons Attribution (CC BY) license (http:/ / creativecommons.org/licenses/by/4.0/). 